\title{
Narrative review of stem cell therapy for ischemic brain injury
}

\author{
Xiao-Li Ji ${ }^{1,2}$, Ling $\mathrm{Ma}^{3}$, Wen-Hao Zhou ${ }^{1,2}$, Man Xiong ${ }^{3}$ \\ ${ }^{1}$ Department of Neonatology, Children's Hospital of Fudan University, Shanghai, China; ${ }^{2}$ Key Laboratory of Neonatal Diseases, Ministry of \\ Health, Children's Hospital of Fudan University, Shanghai, China; ${ }^{3}$ Stem Cell Research Center, Institute of Pediatrics, Children's Hospital, Fudan \\ University, Shanghai, China \\ Contributions: (I) Conception and design: XL Ji, WH Zhou, M Xiong; (II) Administrative support: None; (III) Provision of study materials or patients: \\ None; (IV) Collection and assembly of data: XL Ji, L Ma, M Xiong; (V) Data analysis and interpretation: XL Ji, M Xiong; (VI) Manuscript writing: \\ All authors; (VII) Final approval of manuscript: All authors. \\ Correspondence to: Man Xiong. Stem Cell Research Center, Institute of Pediatrics, Children's Hospital, Fudan University, Shanghai, China. \\ Email: man_xiong@hotmail.com.
}

\begin{abstract}
Ischemic brain injury is a common cause of long-term neurological deficits in children as well as adults, and no efficient treatments could reverse the sequelae in clinic till now. Stem cells have the capacity of self-renewal and multilineage differentiation. The therapeutic efficacy of stem cell transplantation for ischemic brain injury have been tested for many years. The grafts could survive and mature in the ischemic brain environment. Stem cell transplantation could improve functional recovery of ischemic brain injury models in pre-clinical trials. The potential mechanisms included cell replacement, release of neurotrophic and anti-inflammatory factors, immunoregulation as well as activation of endogenous neurogenesis. Besides, many clinical trials were conducted and some of trials already had preliminary results. From the current published data, cell transplantation for clinical application is safe and feasible. No severe adverse events and tumorigenesis were reported. While the therapeutic efficacy of stem cell therapy in clinic still needs more evidences. In this review, we overviewed the studies about stem cell therapy for ischemic brain injury. Different types of stem cells used for transplantation as well as the therapeutic mechanisms were discussed in detail. The related pre-clinical and clinical trials were summarized into two separate tables. In addition, we also discussed the unsolved problems and concerns about stem cell therapy for ischemic brain injury that need to be overcome before clinic transformation.
\end{abstract}

Keywords: Ischemic brain injury; stem cell transplantation; therapeutic mechanism; clinical trials

Submitted Aug 23, 2020. Accepted for publication Dec 18, 2020.

doi: $10.21037 / \mathrm{tp}-20-262$

View this article at: http://dx.doi.org/10.21037/tp-20-262

\section{Introduction}

Ischemic brain injury including stroke, hypoxic-ischemic encephalopathy (HIE) and traumatic brain injury is a high incidence health problem worldwide $(1,2)$. It can cause massive brain tissue infarction, neuronal loss and gliosis, therefore resulting in the occurrence of cerebral palsy, motor defects and even death in immature and mature brain $(3,4)$. Various clinical treatments have been used for ischemic brain injury, such as hyperbaric oxygen (5), medications (6), rehabilitation training (7) and therapeutic hypothermia (8). However, most of these therapeutic methods are supportive care, and none can reverse the sequelae of ischemic encephalopathy.

Since the advent of stem cell biology, one approach to restore the function of ischemic brain injury is stem cell therapy. Many studies have already investigated the therapeutic potentials of stem cell transplantation in ischemic animal models (9-12). Stem cells have the capacity of self-renewal and multilineage differentiation, which could generate plenty of functional cells and migrate to the injured brain areas $(13,14)$. The grafted cells could replace the lost cell type, reconstruct the neural circuitry with host cells, and therefore rebuild the functionality of ischemic 
Table 1 Pre-clinical trials about stem cell transplantation for ischemic brain injury

\begin{tabular}{|c|c|c|c|c|c|c|}
\hline Cell type & $\begin{array}{l}\text { Animal } \\
\text { model }\end{array}$ & Route \& time & Graft maturation & Functional recovery & Theraputic mechanism & Reference \\
\hline $\begin{array}{l}\text { Fetal brain } \\
\text { tissue }\end{array}$ & HIE & $\begin{array}{l}\text { Intracerebral \& } \\
3 \text { days after } \mathrm{HI}\end{array}$ & $\begin{array}{l}\text { Neurochemical phenotype } \\
\text { detected after transplantation for } \\
10-12 \text { weeks }\end{array}$ & $\begin{array}{l}\text { Amelioration of motor } \\
\text { deficits }\end{array}$ & No clarify & (19) \\
\hline ESCs & Stroke & $\begin{array}{l}\text { Intracerebral \& } \\
\text { immediately after } \\
\text { stroke }\end{array}$ & No clarify & $\begin{array}{l}\text { Improvement of the } \\
\text { sensorimotor function }\end{array}$ & No clarify & (20) \\
\hline iPSCs & Stroke & $\begin{array}{l}\text { Intracerebral \& } \\
6 \mathrm{~h} \text { after stroke }\end{array}$ & $\begin{array}{l}\text { Differentiated into GFAP+ neural } \\
\text { cells after transplantation for } \\
28 \text { days }\end{array}$ & $\begin{array}{l}\text { Improvement of motor } \\
\text { function and higher } \\
\text { survival rate }\end{array}$ & $\begin{array}{l}\text { Attenuate cerebral } \\
\text { inflammatory and neural } \\
\text { injury }\end{array}$ & $(21)$ \\
\hline NSCs & Stroke & $\begin{array}{l}\text { Intracerebral \& } \\
7 \text { days after } \\
\text { stroke }\end{array}$ & $\begin{array}{l}\text { Differentiated into neurons, } \\
\text { astrocytes and oligodendrocytes } \\
\text { after transplantation for } 2 \text { months }\end{array}$ & $\begin{array}{l}\text { Improvement in the } \\
\text { sensorimotor function }\end{array}$ & $\begin{array}{l}\text { Graft-host interactions to } \\
\text { stabilize differentiation and } \\
\text { prevent gliotic host } \\
\text { response }\end{array}$ & (22) \\
\hline BM-MSCs & Stroke & $\begin{array}{l}\text { Intracerebral \& } \\
3 \text { days after } \\
\text { stroke }\end{array}$ & $\begin{array}{l}\text { A small percentage neural-like } \\
\text { cells after transplantation for } \\
25 \text { days }\end{array}$ & $\begin{array}{l}\text { Significantly motor } \\
\text { function improvement }\end{array}$ & $\begin{array}{l}\text { Neurotrophic factor } \\
\text { (BDNF, NT-3, VEGF) } \\
\text { production }\end{array}$ & (23) \\
\hline UCB-MSCs & HIE & $\begin{array}{l}\text { Intravenous \& } \\
24 \text { h after HIE }\end{array}$ & $\begin{array}{l}21.3 \% \pm 3.5 \% \text { differentiating into } \\
D C X+\text { neurons }\end{array}$ & $\begin{array}{l}\text { Enhanced behavioral } \\
\text { recovery }\end{array}$ & $\begin{array}{l}\text { Cell replacement and } \\
\text { suppression of gliosis }\end{array}$ & (24) \\
\hline $\begin{array}{l}\text { Adipose- } \\
\text { derivedMSCs }\end{array}$ & Stroke & $\begin{array}{l}\text { Intracerebral \& } \\
24 \text { h after stroke }\end{array}$ & $\begin{array}{l}\text { Few cells expressed GFAP and } \\
\text { NeuN after } 3 \text { days transplantation }\end{array}$ & $\begin{array}{l}\text { Improvement of } \\
\text { neurological function }\end{array}$ & Neurogenesis & $(25)$ \\
\hline $\begin{array}{l}\text { Placenta- } \\
\text { derivedMSCs }\end{array}$ & HIE & $\begin{array}{l}\text { Intracortical \& } 48 \\
\text { h after HIE }\end{array}$ & No clarify & $\begin{array}{l}\text { Improvement of motor } \\
\text { function }\end{array}$ & $\begin{array}{l}\text { Modulation of immune } \\
\text { responses and secretion } \\
\text { the anti-inflammatory } \\
\text { factors }\end{array}$ & $(12)$ \\
\hline
\end{tabular}

HIE, hypoxic ischemic encephalopathy; ESCs, embryonic stem cells; iPSCs, induced pluripotent stem cells; NSCs, neural stem cells; BM-MSCs, bone marrow mesenchymal stem cells; UCB-MSCs, umbilical cord blood mesenchymal stem cells.

injury brain $(15,16)$. In addition, these transplanted stem cells could secrete neurotrophic factors to promote the survival of endogenous residual cells as well as endogenous neurogenesis (17). Besides, through releasing the antiinflammatory cytokines, stem cells could modulate the inflammatory environment of ischemic brain (18). These properties make them as the most promising therapeutic treatment for ischemic encephalopathy in the future.

In this review, we discussed the related studies about stem cells transplantation for ischemic brain injury, summarized the pre-clinical (Table 1) and clinical trials (Table 2) in recent years. And the underlying mechanisms of stem cell therapy, clinical trials as well as unsolved problems were also discussed.

We present the following article in accordance with the Narrative Review Checklist (available at http://dx.doi. org/10.21037/tp-20-262).

\section{Stem cell types used for ischemic brain injury}

Various types of stem cells including fetal cerebral tissues, embryonic stem cells (ESCs)/induced pluripotent stem cells (iPSCs), neural stem cells (NSCs), mesenchymal stem cells (MSCs) and brain organoid were tried for treating ischemic 
Table 2 Main clinical trials about ischemic stroke that have finished or currently being carried out

\begin{tabular}{|c|c|c|c|c|c|c|}
\hline Name of trials & Cells dosage & $\begin{array}{l}\text { Patients } \\
\text { recruited }\end{array}$ & $\begin{array}{l}\text { Deliver } \\
\text { route }\end{array}$ & Follow-up & Outcome measures & Therapeutic efficacy \\
\hline $\begin{array}{l}\text { Study of allogeneic } \\
\text { BM-MSCs in subjects } \\
\text { with ischemic stroke } \\
\text { (NCT01297413) }\end{array}$ & $\begin{array}{l}0.5-1.5 \\
\text { million/kg }\end{array}$ & 38 & IV & 12 months & Safety and tolerability & Function benefits \\
\hline $\begin{array}{l}\text { Infusion of BM-MNCs in } \\
\text { subacute ischemic stroke } \\
\text { patients (NCT03080571) }\end{array}$ & $\begin{array}{l}\text { No } \\
\text { description }\end{array}$ & 20 & IA & 6 months & $\begin{array}{l}\text { 1. Change in NISS score; } \\
\text { 2. Symptomatic intracranial } \\
\text { hemorrhage; 3. New ischemic } \\
\text { lesion; 4. Death }\end{array}$ & $\begin{array}{l}\text { No relevant results published } \\
\text { yet }\end{array}$ \\
\hline $\begin{array}{l}\text { Autologous BM-MNCs } \\
\text { in stroke patients } \\
\text { (NCT00859014) }\end{array}$ & 10 million/kg & 25 & IV & 24 months & $\begin{array}{l}\text { 1.Safety and feasibility; } \\
\text { 2. Functional outcome }\end{array}$ & $\begin{array}{l}\text { 1.No study-related severe } \\
\text { adverse events; } 2 \text {. A better } \\
\text { outcome on NIHSS and mRS } \\
\text { scale }\end{array}$ \\
\hline $\begin{array}{l}\text { Reparative therapy in } \\
\text { acute ischemic stroke with } \\
\text { allogenic MSCs from } \\
\text { adipose (NCT01678534) }\end{array}$ & 1 million/kg & 19 & IV & 24 months & $\begin{array}{l}\text { 1. Adverse events; } \\
\text { 2. Neurological and systemic } \\
\text { complications; } \\
\text { 3. Tumorgenesis }\end{array}$ & $\begin{array}{l}\text { No relevant results published } \\
\text { yet }\end{array}$ \\
\hline $\begin{array}{l}\text { Effect of different } \\
\text { transplantation Time for } \\
\text { UC-MSCs in stroke patients } \\
\text { (NCT04093336) }\end{array}$ & 2 million $/ \mathrm{kg}$ & 120 & IV & 24 months & $\begin{array}{l}\text { Assess the adverse events, } \\
\text { neurological functional recovery } \\
\text { and quality of life }\end{array}$ & Ongoing \\
\hline
\end{tabular}

BM-MSCs, bone marrow mesenchymal stem cells; BM-MNCs, bone marrow mononuclear cells; UC-MSCs, umbilical cord blood mesenchymal stem cells; NIHSS, national institute of health stroke scale; NSCs, neural stem cells.

brain injury (Figure 1).

\section{Fetal cerebral tissues}

The fetal cerebral tissues used for transplantation were obtained from different gestational ages and anatomical sites. Various cell types, such as NSCs, neurons, astrocytes and oligodendrocytes can be isolated from fetal cerebral tissues $(27,28)$. Studies had demonstrated the survival, migration and therapeutic efficacy of fetal cerebral tissues derived from rodents or human after being transplanted into the ischemic brain $(19,29,30)$. Elsayed et al. (19) showed that transplants obtained from embryonic day 13 rat fetus survived in over $80 \%$ of the HIE animal models 


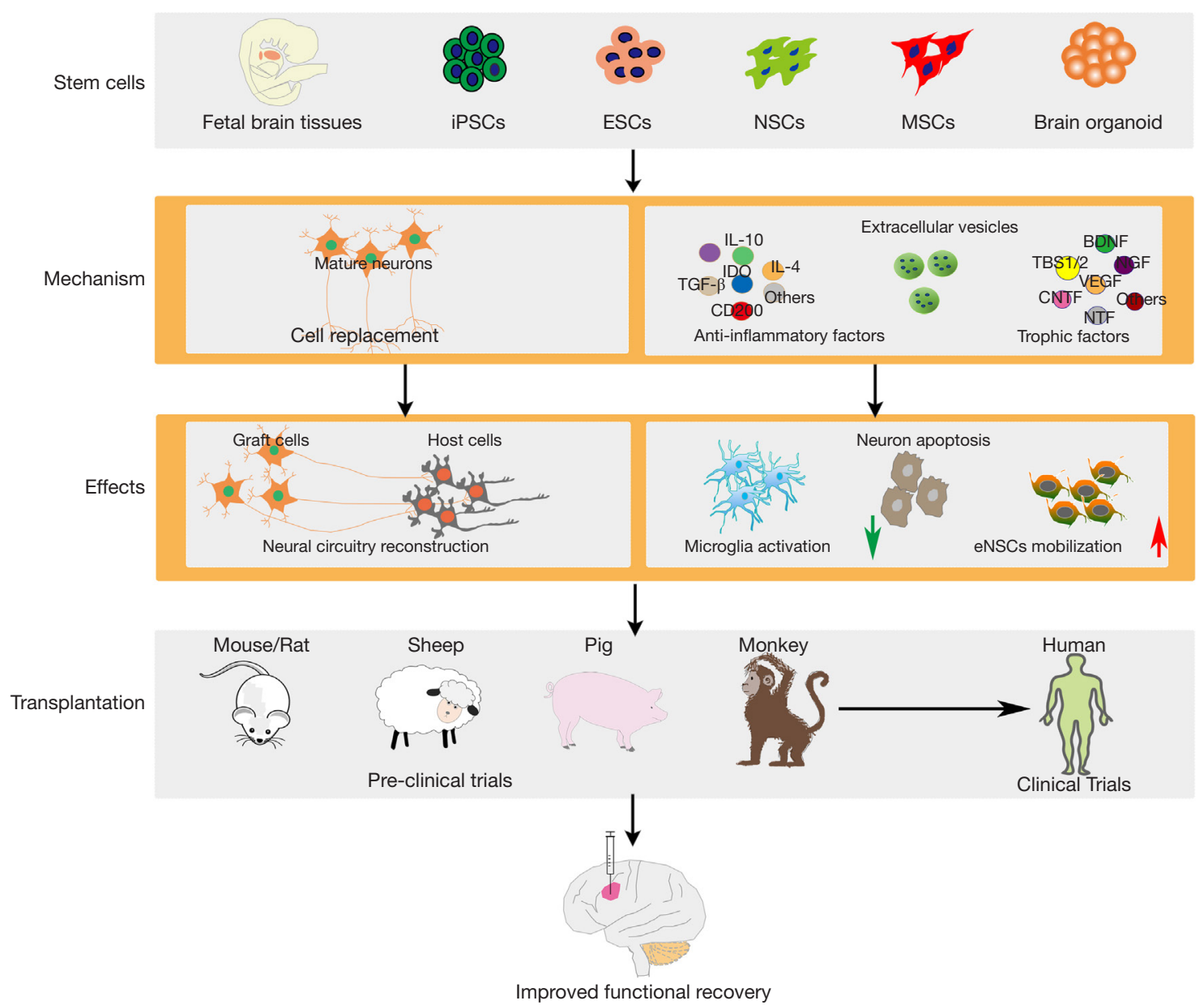

Figure 1 Stem cell types and therapeutic mechanism for treating ischemic brain injury. ESCs, embryonic stem cells; iSCs, induced pluripotent stem cells; eNSCs, endogeneous neural stem cells; MSCs, mesenchymal stem cells.

and acetylcholinesterase-positive fibers derived from transplants were extensively distributed at the graft-host interface after 6 weeks transplantation. Jansen et al. (27) transplanted cell suspension which were digested from fetal neocortical tissues into the motor cortex of HIE model. Survived cells could be detected in $72 \%$ of model animals, and the cell transplanted group performed better motor function than the control group 10-12 weeks after transplantation. Another study indicated that transplanting fetal frontal cortex into the injured brain could improve the motor defects, while surgical removal of transplants led to motor defects again (31). The fetal tissue was the first cell source tried for transplantation and demonstrated to be effective. While the usage of fetal cerebral tissues for treating ischemic brain injury in patients are limited due to the ethical issue.

\section{ESCs/iPSCs}

ESCs are derived from the inner cell mass of the blastocyst and have the broadest potentials to generate all cell types in vivo and in vitro (32). The totipotent ESCs could be differentiated into functional neurons and astrocytes with specific induction protocols in vitro $(33,34)$. Lee et al. (20) explored the therapeutic efficacy of ESCs for ischemic encephalopathy. They found that there was a progressive reduction in infarction size in ESCs treatment group. Neurological severity score indicated an early beneficial effect and performed significantly better than control group. IPSCs are a population of cells which are reprogrammed from terminally differentiated somatic cells and possess the same self-renewal and differentiation capacity as ESCs $(35,36)$. Reprogramming of somatic cells 
to iPSCs produce patient-originated cells without concern of immunosuppression after autologous transplantation. Qin et al. (21) transplanted rat-derived iPSCs into stroke animal model. The transplanted iPSCs differentiated into $\mathrm{GFAP}^{+}$neural cells after transplantation for 28 days. IPSCs treatment significantly reduced the number of neutrophils, microglia and the inflammatory cytokines including TNF- $\alpha$, IL-1 $\beta$ and IL- 6 . They also observed the motor function by MLPT scores, and the scores showed that iPSCs transplantation significantly improved ischemic rat's motor function from day 14 to day 42 post transplantation. Furthermore, the survival rate of rats in iPSCs group $(83.33 \%)$ was higher than that of control group (66.67\%) (37). Although the ESCs/iPSCs have the optimal differentiated potential toward neural cells, the side-effects including tumorigenesis and instability are severe safety concerns. These side-effects could significantly affect the functional recovery of ischemic animal models $(38,39)$. Studies indicated that direct differentiation ESCs/ iPSCs into NSCs/MSCs for transplantation could greatly reduce the risk of tumorigenesis and the therapeutic efficacy of NSCs/MSCs was obvious $(40,41)$.

\section{Neural stem/progenitor cells}

NSCs/NPCs are a population of cells in central nervous system which have the capacity of self-renewal and differentiation into neurons, astrocytes, and oligodendrocytes $(42,43)$. In embryonic stage of mammals, NSCs are widely distributed in various regions of the brain, such as cerebral cortex, hippocampus, subventricular layer (44). While in adult brain, the NSCs mainly exist in subventricular and subgranular zone and maintain in a resting state (45). Once the brain injury occurs, these resting NSCs begin to proliferate and participate in the repair of brain injury (46). However, it is estimated that in patients with severe cerebral ischemia, about 120 million neurons are lost per hour during the acute ischemic period (47). Massive lost neurons cannot be replaced only relying on the endogenous NSCs proliferation. Therefore, transplantation of exogenous NSCs is a potential treatment for the repair of ischemic brain injury.

Most NSCs/NPCs used for cell transplantation are usually obtained by two ways, one is differentiated from ESCs or iPSCs $(48,49)$, and the other is isolated from fetal or adult brain tissues $(50,51)$. Many studies have demonstrated the therapeutic efficacy of NSCs transplantation for ischemic brain injury. In ischemic brain, the survived NSCs differentiated into neurons expressing Tuj1, DCX, and GAD, and astrocytes expressing GFAP after transplantation for 4 weeks (22). In addition to differentiation into neurons, transplanted NPCs could also recruit the endogenous oligodendrocytes to myelinate the corpus callosum and reduce the glial scar formation (52), which were beneficial to the functional recovery of ischemic animal models. One ideal goal of stem cell therapy is to generate specific neurons to reconstruct the endogenous neural circuitry. Therefore, fate-committed neuronal progenitors seem to be much suitable for cell transplantation. Tornero et al. (53) generated neuronal progenitors with a cortical phenotype in vitro, and these fated cells could differentiate into TBR1+ cortical neurons after being transplantation in stroke-damaged cortex. And these cortical-fated cells induced motor function improvement. Importantly, no chromosome abnormalities and tumor formation were found after NSCs/NPCs transplantation for a long time.

\section{MSCs}

MSCs are adult stem cells which can be isolated from various tissues, such as bone marrow, umbilical cord blood, placental tissue and adipose tissue $(24,25,54)$. MSCs derived from different tissues have similar biological characteristics, including low immunogenicity, capacity of proliferation, differentiation and secretion. Therefore, MSCs were largely used to treat ischemic brain injury in pre-clinical and clinical trials. The improvement of neurobehavioral functions were observed after transplantation from a shortterm (48 h) (11) to a long-term (14 months) in ischemic animal models $(55,56)$. However, the long-term survival of MSCs and its capacity of generating new "neuronal" cells after transplantation in vivo were controversial. van Velthoven et al. (57) found that less than $1 \%$ of transplanted MSCs could be detected after transplantation in HIE model for 18 days. One study reported that although bone marrow derived MSCs expressed markers of astrocytes (GFAP+), oligodendroglia (GalC+), and neurons (NF160+, NF200+, hNSE+, hNF70+) after 6 weeks transplantation. While these new "neuronal" cells were in nature with few processes and the functional recovery of ischemic rat was unlikely due to these new "neuronal" cells (58). Researchers considered the therapeutic efficacy of MSCs relying on cytokines secretion, immunoregulation and promotion of endogenous NSCs proliferation (23,59-61). No matter which mechanisms, the therapeutic efficacy of MSCs in pre- 
clinical ischemic encephalopathy models were obvious.

\section{Brain organoid}

Brain organoid is an artificial mini brain differentiated from ESCs or iPSCs in vitro. It contains various cell types including NSCs, neurons, astrocytes and oligodendrocytes $(26,62)$. Cerebral organoids showed potentials of multilineage differentiation in ischemic brain injury models after transplantation. They could mimic the cortical development, promote motor cortex region-specific reconstruction and form synaptic connection with host brain (63). Thus, these three-dimensional neural tissues which contain progenitor zone and rudimentary cortical layers are a potential resource for ischemic encephalopathy in the future.

\section{Mechanisms of stem cell therapy for ischemic brain injury}

Transplanted cells have been demonstrated to improve functional recovery in animal model of ischemic brain injury through various mechanisms such as cell replacement, neurotrophy, immunomodulation and neurogenesis (Figure 1).

\section{Cell replacement and functional integration with bost neural circuitry}

Massive neuronal cells loss induced by the ischemic brain injury is the main cause of the secondary cerebral palsy and mental retardation. Replacement of the lost neurons is the most potential way to rebuild the functionality of injured brain after ischemia. Many studies have demonstrated that stem cells derived from various sources could survive and mature into different neuronal cell types in ischemic brain, such as GABA neurons (64), glutamate neurons, dopamine and serotonin neurons (65). Besides, astrocytes and oligodendrocytes could also be obtained in the grafts (66). Although transplanted cells could differentiate into mature neurons in vivo, the long-term survival and functional reconstruction of the neural circuitry in injured brain is the key point for stem cell therapy. Tornero et al. (53) showed that the grafted cells could mature into cortical neurons 2 months after transplantation and the grafted cells exhibited properties of mature neurons morphologically and electrophysiologically after being transplanted for 5 months. Importantly, the grated cells could receive direct inputs from host cells which indicated the functional neural circuitry formation (16). Furthermore, they demonstrated that grafted cells could integrate into the neural circuitry of the host and therefore affect animals' motor behavior (15). However, not all cell types could differentiate into mature neural cells and play the role of cell replacement after transplantation in vivo due to its original characteristics. Many studies indicated that NSCs/ NPCs had the capacity of differentiation into mature neurons and integration into host neural circuitry $(15,16)$, while it seemed that MSCs couldn't generate new functional "neuronal" cells after being transplanted in ischemic animal models (58).

\section{Modulation of inflammatory microenvironment}

Microglia and astrocytes are activated within minutes after ischemic brain injury and some cytokines (IL-6, TNF- $\alpha$, IL-1 $\alpha$, etc.) and chemokines (CXCL1, CCR2, CCL2) were released, which further attracted the immune cells migrating to the ischemic sites and worsened the injured brain (67-69). Many studies explored anti-inflammatory and immunomodulatory function of stem cells in vitro and in vivo. The stem cells inhibited pro-inflammatory cytokines (IFN- $\gamma, \mathrm{TNF}-\alpha, \mathrm{IL}-17$, etc.) production in ischemic injured brain (12) by up-regulating the antiinflammatory factors (TGF- $\beta$, IL-10, IL-4, CD200, etc.) $(70,71)$. Chemokines MCP-1 and MIP- $1 \alpha$ are indicators of microglial/ macrophage activation. Huang et al. (18) demonstrated in their study that NSCs transplantation could significantly downregulate the expression of both chemokines, and therefore reduce transit of neutrophils and monocytes into the brain. Extracellular vesicles derived from MSCs are nanoscale vesicles which could modulate central and peripheral inflammation (72). Many studies showed that grafted MSCs could improve functional recovery by secreting extracellular vesicles to alleviate the neuroinflammation in ischemic brain injury models of monkeys (73), ovine (72), and rats (74). These results demonstrate the anti-inflammatory and immunomodulation effect of stem cells after transplantation in vivo. In addition, through modulating the inflammatory microenvironment, stem cells could inhibit apoptosis and therefore more residual neurons in ischemic area survived and benefited to the functional recovery (17). It is demonstrated that almost all stem cell types used for transplantation have the capacity of anti-inflammation and immunomodulation in vivo $(18,37,75)$. 


\section{Neurotrophy and neurogenesis}

Except the exogenous cell replacement, the survival and neurogenesis of endogenous cells is also very important for the functional recovery of ischemic brain injury (76). Stroke alone could stimulate neurogenesis at the subventricular zone. While stem cells treatment could significantly augment this neurogenic activity by secreting the neurotrophic factors (77). Neurotrophic factors are a group of short-lived proteins, showing efficacy of improving endogenous and exogenous stem cells survival and maturation previously $(78,79)$. Many studies detected the secretion of neurotrophic factors by stem cells in vitro and in vivo $(22,80)$. Oshita et al. $(75)$ indicated in their research that bone marrow-derived MSCs promoted functional recovery through strong expression of BDNF and VEGF. Another study detected the increased secretion of NGF, BDNF, NTF3, FGF9, CNTF and TBS1/2 in NPCs culture medium under oxygen and glucose deprivation model. They postulated that the transplanted NPCs promoted functional recovery via secreting multiple factors which enhanced the neuronal survival and neuroplasticity (81). In addition, the neurotrophic factors secreted by grafted cells could enhance endogenous neurogenesis, more new cells $\left(\mathrm{BrdU}^{+} / \mathrm{NeuN}^{+}\right)$ were observed 4 weeks after ischemic brain injury (55).

\section{Clinical trials about stem cells therapy for ischemic brain injury}

The therapeutic efficacy of stem cells has been demonstrated in lots of pre-clinical experiments. In recent years, various small or large-scale clinical trials have been underway, and many of them already showed preliminary results (see Table 2). Most stem cell types used for clinical trials were MSCs and NSCs. A clinical trial recruited 30 patients with severe stroke, and 5 patients received intravenous infusion of $1 \times 10^{8}$ autologous MSCs transplantation while another 25 patients were as the control group. After one-year follow-up, they found no adverse cell-related, serological, or imaging-defined effects in stroke patient. The Barthel index which indicates the functional recovery showed greater improvement than that of control patients from beginning to the end of the follow-up (82). A two-year open-label, single-site, and dose-escalation clinical trial (NCT01151124) about NSCs treating for stroke patients was completed. Analysis of clinical data showed that single intracerebral doses of NSCs up to 20 million cells induced no adverse events and were associated with improved neurological function (83).
Concerns about the zoonoses caused by the usage of xenogeneic culture medium and diminishment of functional recovery with time need to be verified in long-term followup. Lee et al. (84) conducted a five-year follow-up of autologous MSCs transplantation in patient with ischemic stroke. They demonstrated the beneficial effect of MSCs transplantation in terms of functional outcome and survival in stroke patients during long-term follow-up. Besides, many other clinical trials about stem cell therapy for ischemic patients are ongoing (https://clinicaltrials). From the current published data, cell transplantation for clinical application is safe and feasible. No severe adverse events and tumorigenesis were reported. While the functional outcomes still need to be assessed in more and lager cohort studies.

\section{Perspectives}

Currently, stem cell therapy is the most promising treatment for ischemic brain injury. And cell transplantation from bench to bed provides great hope for patients with ischemic brain injury. While many issues still need to be clarified before clinical application. For stem cell therapy to succeed in neurological deficits, the grafted cells should replace the lost neuronal type and reconstruct the corresponding neural circuitry with host cells $(85,86)$. In ischemic brain injury, more evidences are needed to further support the conclusion that the long-term functional recovery is related to the neural circuitry reconstruction. In addition, which cell types should be chosen for treating ischemic injured patients at different stages? Is there any difference for surviving, proliferation, differentiation and functional integration of stem cells in mature and immature brain? Besides, the way and cell dosage for stem cell therapy also need to be clarified. Many studies tried the route including intracranial (15), intravenous (59), intranasal (76) or intraperitoneal injection (87). Each route has pros and cons. In clinical application, patient's physical status should be taken into consideration before choosing the injection route. In addition, ischemic encephalopathy always has many comorbidities such as hypertension, seizure and headache (88). Therefore, the stem cell therapy for ischemic brain injury with severe complications should be studied thoroughly before clinical application.

\section{Acknowledgments}

Funding: This study was supported by the grant 2017YQ074 from Outstanding Youth Program of Shanghai and 
EK112520180209 from "Deng Feng" Cross Innovation Program.

\section{Footnote}

Reporting Checklist: The authors have completed the Narrative Review Checklist. Available at http://dx.doi. org/10.21037/tp-20-262

Peer Review File: Available at http://dx.doi.org/10.21037/tp20-262

Conflicts of Interest: All authors have completed the ICMJE uniform disclosure form (available at http://dx.doi. org/10.21037/tp-20-262). The authors have no conflicts of interest to declare.

Ethical Statement: The authors are accountable for all aspects of the work in ensuring that questions related to the accuracy or integrity of any part of the work are appropriately investigated and resolved.

Open Access Statement: This is an Open Access article distributed in accordance with the Creative Commons Attribution-NonCommercial-NoDerivs 4.0 International License (CC BY-NC-ND 4.0), which permits the noncommercial replication and distribution of the article with the strict proviso that no changes or edits are made and the original work is properly cited (including links to both the formal publication through the relevant DOI and the license). See: https://creativecommons.org/licenses/by-nc-nd/4.0/.

\section{References}

1. Ogata J, Yamanishi H, Pantoni L. Neuropathology of ischemic brain injury. Handb Clin Neurol 2009;92:93-116.

2. Meixensberger J, Roosen K. Clinical and pathophysiological significance of severe neurotrauma in polytraumatized patients. Langenbecks Arch Surg 1998;383:214-9.

3. Doyle KP, Simon RP, Stenzel-Poore MP. Mechanisms of ischemic brain damage. Neuropharmacology 2008;55:310-8.

4. Chan PH. Reactive oxygen radicals in signaling and damage in the ischemic brain. J Cereb Blood Flow Metab 2001;21:2-14.

5. Yin D, Zhou C, Kusaka I, et al. Inhibition of apoptosis by hyperbaric oxygen in a rat focal cerebral ischemic model. J
Cereb Blood Flow Metab 2003;23:855-64.

6. Liu Z, Li P, Zhao D, et al. Protective effect of extract of Cordyceps sinensis in middle cerebral artery occlusioninduced focal cerebral ischemia in rats. Behav Brain Funct 2010;6:61.

7. Biernaskie J, Corbett D. Enriched rehabilitative training promotes improved forelimb motor function and enhanced dendritic growth after focal ischemic injury. J Neurosci 2001;21:5272-80.

8. Xiong M, Ma SM, Shao XM, et al. Hypoxic ischaemic hypothermia promotes neuronal differentiation and inhibits glial differentiation from newly generated cells in the SGZ of the neonatal rat brain. Neurosci Lett 2012;523:87-92.

9. Li Y, Chen J, Chen XG, et al. Human marrow stromal cell therapy for stroke in rat: neurotrophins and functional recovery. Neurology 2002;59:514-23.

10. Ryu S, Lee SH, Kim SU, et al. Human neural stem cells promote proliferation of endogenous neural stem cells and enhance angiogenesis in ischemic rat brain. Neural Regen Res 2016;11:298-304.

11. Xu J, Feng Z, Wang X, et al. hUC-MSCs Exert a Neuroprotective Effect via Anti-apoptotic Mechanisms in a Neonatal HIE Rat Model. Cell Transplant 2019;28:1552-9.

12. Ding $\mathrm{H}$, Zhang $\mathrm{H}$, Ding $\mathrm{H}$, et al. Transplantation of placentaderived mesenchymal stem cells reduces hypoxic-ischemic brain damage in rats by ameliorating the inflammatory response. Cell Mol Immunol 2017;14:693-701.

13. Moore KA, Lemischka IR. Stem cells and their niches. Science 2006;311:1880-5.

14. Meyer P, Grandgirard D, Lehner M, et al. Grafted Neural Progenitor Cells Persist in the Injured Site and Differentiate Neuronally in a Rodent Model of Cardiac Arrest-Induced Global Brain Ischemia. Stem Cells Dev 2020;29:574-85.

15. Palma-Tortosa S, Tornero D, Grønning Hansen M, et al. Activity in grafted human iPS cell-derived cortical neurons integrated in stroke-injured rat brain regulates motor behavior. Proc Natl Acad Sci U S A 2020;117:9094-100.

16. Tornero D, Tsupykov O, Granmo M, et al. Synaptic inputs from stroke-injured brain to grafted human stem cell-derived neurons activated by sensory stimuli. Brain 2017;140:692-706.

17. Li F, Zhang K, Liu H, et al. The neuroprotective effect of mesenchymal stem cells is mediated through inhibition of apoptosis in hypoxic ischemic injury. World J Pediatr 2020;16:193-200.

18. Huang L, Wong S, Snyder EY, et al. Human neural stem 
cells rapidly ameliorate symptomatic inflammation in early-stage ischemic-reperfusion cerebral injury. Stem Cell Res Ther 2014;5:129.

19. Elsayed MH, Hogan TP, Shaw PL, et al. Use of fetal cortical grafts in hypoxic-ischemic brain injury in neonatal rats. Exp Neurol 1996;137:127-41.

20. Lee TH. Behavioral assessment of cell transplantation after focal cerebral ischemia in rats. J Exerc Rehabil 2015;11:140-4.

21. Qin J, Gong G, Sun S, et al. Functional recovery after transplantation of induced pluripotent stem cells in a rat hemorrhagic stroke model. Neurosci Lett 2013;554:70-5.

22. Daadi MM, Davis AS, Arac A, et al. Human neural stem cell grafts modify microglial response and enhance axonal sprouting in neonatal hypoxic-ischemic brain injury. Stroke 2010;41:516-23.

23. Bao X, Wei J, Feng M, et al. Transplantation of human bone marrow-derived mesenchymal stem cells promotes behavioral recovery and endogenous neurogenesis after cerebral ischemia in rats. Brain Res 2011;1367:103-13.

24. Zhang X, Zhang Q, Li W, et al. Therapeutic effect of human umbilical cord mesenchymal stem cells on neonatal rat hypoxic-ischemic encephalopathy. J Neurosci Res 2014;92:35-45.

25. Lam PK, Wang KKW, Chin DWC, et al. Topically applied adipose-derived mesenchymal stem cell treatment in experimental focal cerebral ischemia. J Clin Neurosci 2020;71:226-33.

26. Lancaster MA, Renner M, Martin CA, et al. Cerebral organoids model human brain development and microcephaly. Nature 2013;501:373-9.

27. Jansen EM, Solberg L, Underhill S, et al. Transplantation of fetal neocortex ameliorates sensorimotor and locomotor deficits following neonatal ischemic-hypoxic brain injury in rats. Exp Neurol 1997;147:487-97.

28. Kelly S, Bliss TM, Shah AK, et al. Transplanted human fetal neural stem cells survive, migrate, and differentiate in ischemic rat cerebral cortex. Proc Natl Acad Sci U S A 2004;101:11839-44.

29. Qu SQ, Luan Z, Yin GC, et al. Transplantation of human fetal neural stem cells into cerebral ventricle of the neonatal rat following hypoxic-ischemic injury: survival, migration and differentiation. Zhonghua Er Ke Za Zhi 2005;43:576-9.

30. Lee HJ, Kim KS, Kim EJ, et al. Brain transplantation of immortalized human neural stem cells promotes functional recovery in mouse intracerebral hemorrhage stroke model. Stem Cells 2007;25:1204-12.
31. Sandor R, Gonzalez MF, Moseley M, et al. Motor deficits are produced by removing some cortical transplants grafted into injured sensorimotor cortex of neonatal rats. J Neural Transplant Plast 1991;2:221-33.

32. Thomson JA, Itskovitz-Eldor J, Shapiro SS, et al. Embryonic stem cell lines derived from human blastocysts. Science 1998;282:1145-7.

33. Maroof AM, Keros S, Tyson JA, et al. Directed differentiation and functional maturation of cortical interneurons from human embryonic stem cells. Cell Stem Cell 2013;12:559-72.

34. Li X, Tao Y, Bradley R, et al. Fast Generation of Functional Subtype Astrocytes from Human Pluripotent Stem Cells. Stem Cell Reports 2018;11:998-1008.

35. Yu J, Vodyanik MA, Smuga-Otto K, et al. Induced pluripotent stem cell lines derived from human somatic cells. Science 2007;318:1917-20.

36. Takahashi K, Yamanaka S. Induction of pluripotent stem cells from mouse embryonic and adult fibroblast cultures by defined factors. Cell 2006;126:663-76.

37. Qin J, Ma X, Qi H, et al. Transplantation of Induced Pluripotent Stem Cells Alleviates Cerebral Inflammation and Neural Damage in Hemorrhagic Stroke. PLoS One 2015;10:e0129881.

38. Kawai H, Yamashita T, Ohta Y, et al. Tridermal tumorigenesis of induced pluripotent stem cells transplanted in ischemic brain. J Cereb Blood Flow Metab 2010;30:1487-93

39. Erdö F, Buhrle C, Blunk J, et al. Host-dependent tumorigenesis of embryonic stem cell transplantation in experimental stroke. J Cereb Blood Flow Metab 2003;23:780-5.

40. Yuan T, Liao W, Feng NH, et al. Human induced pluripotent stem cell-derived neural stem cells survive, migrate, differentiate, and improve neurologic function in a rat model of middle cerebral artery occlusion. Stem Cell Res Ther 2013;4:73.

41. Oki K, Tatarishvili J, Wood J, et al. Human-induced pluripotent stem cells form functional neurons and improve recovery after grafting in stroke-damaged brain. Stem Cells 2012;30:1120-33.

42. Doe CQ. Neural stem cells: balancing self-renewal with differentiation. Development 2008;135:1575-87.

43. Tzeng SF. Neural progenitors isolated from newborn rat spinal cords differentiate into neurons and astroglia. J Biomed Sci 2002;9:10-6.

44. Martín-Ibáñez R, Guardia I, Pardo M, et al. Insights in spatio-temporal characterization of human fetal neural 
stem cells. Exp Neurol 2017;291:20-35.

45. Jin K, Galvan V. Endogenous neural stem cells in the adult brain. J Neuroimmune Pharmacol 2007;2:236-42.

46. Huang L, Zhang L. Neural stem cell therapies and hypoxicischemic brain injury. Prog Neurobiol 2019;173:1-17.

47. Saver JL. Time is brain--quantified. Stroke 2006;37:263-6.

48. Zhang SC, Wernig M, Duncan ID, et al. In vitro differentiation of transplantable neural precursors from human embryonic stem cells. Nat Biotechnol 2001;19:1129-33.

49. Jendelova P, Sykova E, Erceg S. Neural Stem Cells Derived from Human-Induced Pluripotent Stem Cells and Their Use in Models of CNS Injury. Results Probl Cell Differ 2018;66:89-102.

50. Schwartz PH, Bryant PJ, Fuja TJ, et al. Isolation and characterization of neural progenitor cells from postmortem human cortex. J Neurosci Res 2003;74:838-51.

51. Andres RH, Horie N, Slikker W, et al. Human neural stem cells enhance structural plasticity and axonal transport in the ischaemic brain. Brain 2011;134:1777-89.

52. Rumajogee P, Altamentova S, Li L, et al. Exogenous Neural Precursor Cell Transplantation Results in Structural and Functional Recovery in a HypoxicIschemic Hemiplegic Mouse Model. eNeuro 2018;5:ENEURO.0369-18.2018.

53. Tornero D, Wattananit S, Gronning Madsen M, et al. Human induced pluripotent stem cell-derived cortical neurons integrate in stroke-injured cortex and improve functional recovery. Brain 2013;136:3561-77.

54. Chen Y, Shao JZ, Xiang LX, et al. Mesenchymal stem cells: a promising candidate in regenerative medicine. Int $\mathrm{J}$ Biochem Cell Biol 2008;40:815-20.

55. Jeong CH, Kim SM, Lim JY, et al. Mesenchymal stem cells expressing brain-derived neurotrophic factor enhance endogenous neurogenesis in an ischemic stroke model. Biomed Res Int 2014;2014:129145.

56. Donega V, Nijboer CH, van Velthoven CT, et al. Assessment of long-term safety and efficacy of intranasal mesenchymal stem cell treatment for neonatal brain injury in the mouse. Pediatr Res 2015;78:520-6.

57. van Velthoven CT, Kavelaars A, van Bel F, et al. Mesenchymal stem cell transplantation changes the gene expression profile of the neonatal ischemic brain. Brain Behav Immun 2011;25:1342-8.

58. Zhao LR, Duan WM, Reyes M, et al. Human bone marrow stem cells exhibit neural phenotypes and ameliorate neurological deficits after grafting into the ischemic brain of rats. Exp Neurol 2002;174:11-20.
59. Sugiyama Y, Sato Y, Kitase Y, et al. Intravenous Administration of Bone Marrow-Derived Mesenchymal Stem Cell, but not Adipose Tissue-Derived Stem Cell, Ameliorated the Neonatal Hypoxic-Ischemic Brain Injury by Changing Cerebral Inflammatory State in Rat. Front Neurol 2018;9:757.

60. van Velthoven CT, Kavelaars A, van Bel F, et al.

Mesenchymal stem cell treatment after neonatal hypoxicischemic brain injury improves behavioral outcome and induces neuronal and oligodendrocyte regeneration. Brain Behav Immun 2010;24:387-93.

61. Yu X, Wu H, Zhao Y, et al. Bone marrow mesenchymal stromal cells alleviate brain white matter injury via the enhanced proliferation of oligodendrocyte progenitor cells in focal cerebral ischemic rats. Brain Res 2018;1680:127-36.

62. Wang Z, Wang SN, Xu TY, et al. Organoid technology for brain and therapeutics research. CNS Neurosci Ther 2017;23:771-8.

63. Wang SN, Wang Z, Xu TY, et al. Cerebral Organoids Repair Ischemic Stroke Brain Injury. Transl Stroke Res 2020;11:983-1000.

64. Abeysinghe HC, Bokhari L, Quigley A, et al. Predifferentiation of human neural stem cells into GABAergic neurons prior to transplant results in greater repopulation of the damaged brain and accelerates functional recovery after transient ischemic stroke. Stem Cell Res Ther 2015;6:186.

65. Takagi Y, Nishimura M, Morizane A, et al. Survival and differentiation of neural progenitor cells derived from embryonic stem cells and transplanted into ischemic brain. J Neurosurg 2005;103:304-10.

66. Bühnemann C, Scholz A, Bernreuther C, et al. Neuronal differentiation of transplanted embryonic stem cellderived precursors in stroke lesions of adult rats. Brain 2006;129:3238-48.

67. Stoll G, Jander S, Schroeter M. Inflammation and glial responses in ischemic brain lesions. Prog Neurobiol 1998;56:149-71.

68. Song H, Zhang X, Chen R, et al. Cortical NeuronDerived Exosomal MicroRNA-181c-3p Inhibits Neuroinflammation by Downregulating CXCL1 in Astrocytes of a Rat Model with Ischemic Brain Injury. Neuroimmunomodulation 2019;26:217-33.

69. Luo YJ, Li RB, Ma SY, et al. Progress on Hypoxicischemic Brain Damage Associated with CCR2 and CCL2. Fa Yi Xue Za Zhi 2016;32:54-7.

70. Redondo-Castro E, Cunningham C, Miller J, et al. Interleukin-1 primes human mesenchymal stem cells 
towards an anti-inflammatory and pro-trophic phenotype in vitro. Stem Cell Res Ther 2017;8:79.

71. Kong T, Park JM, Jang JH, et al. Immunomodulatory effect of CD200-positive human placenta-derived stem cells in the early phase of stroke. Exp Mol Med 2018;50:e425.

72. Ophelders DR, Wolfs TG, Jellema RK, et al. Mesenchymal Stromal Cell-Derived Extracellular Vesicles Protect the Fetal Brain After Hypoxia-Ischemia. Stem Cells Transl Med 2016;5:754-63.

73. Go V, Bowley BGE, Pessina MA, et al. Extracellular vesicles from mesenchymal stem cells reduce microglialmediated neuroinflammation after cortical injury in aged Rhesus monkeys. Geroscience 2020;42:1-17.

74. Dabrowska S, Andrzejewska A, Strzemecki D, et al. Human bone marrow mesenchymal stem cell-derived extracellular vesicles attenuate neuroinflammation evoked by focal brain injury in rats. J Neuroinflammation 2019;16:216.

75. Oshita J, Okazaki T, Mitsuhara T, et al. Early Transplantation of Human Cranial Bone-derived Mesenchymal Stem Cells Enhances Functional Recovery in Ischemic Stroke Model Rats. Neurol Med Chir (Tokyo) 2020;60:83-93.

76. Chau MJ, Deveau TC, Gu X, et al. Delayed and repeated intranasal delivery of bone marrow stromal cells increases regeneration and functional recovery after ischemic stroke in mice. BMC Neurosci 2018;19:20.

77. Baker EW, Platt SR, Lau VW, et al. Induced Pluripotent Stem Cell-Derived Neural Stem Cell Therapy Enhances Recovery in an Ischemic Stroke Pig Model. Sci Rep 2017;7:10075.

78. Barde YA. Trophic factors and neuronal survival. Neuron

Cite this article as: Ji XL, Ma L, Zhou WH, Xiong M. Narrative review of stem cell therapy for ischemic brain injury. Transl Pediatr 2021;10(2):435-445. doi: 10.21037/tp-20-262
1989;2:1525-34.

79. Lewin GR, Barde YA. Physiology of the neurotrophins. Annu Rev Neurosci 1996;19:289-317.

80. Hass R, Kasper C, Bohm S, et al. Different populations and sources of human mesenchymal stem cells (MSC): A comparison of adult and neonatal tissue-derived MSC. Cell Commun Signal 2011;9:12.

81. Lee IS, Koo KY, Jung K, et al. Neurogenin-2-transduced human neural progenitor cells attenuate neonatal hypoxicischemic brain injury. Transl Res 2017;183:121-36.e9.

82. Bang OY, Lee JS, Lee PH, et al. Autologous mesenchymal stem cell transplantation in stroke patients. Ann Neurol 2005;57:874-82.

83. Kalladka D, Sinden J, Pollock K, et al. Human neural stem cells in patients with chronic ischaemic stroke (PISCES): a phase 1, first-in-man study. Lancet 2016;388:787-96.

84. Lee JS, Hong JM, Moon GJ, et al. A long-term followup study of intravenous autologous mesenchymal stem cell transplantation in patients with ischemic stroke. Stem Cells 2010;28:1099-106.

85. Chen Y, Xiong M, Dong Y, et al. Chemical Control of Grafted Human PSC-Derived Neurons in a Mouse Model of Parkinson's Disease. Cell Stem Cell 2016;18:817-26.

86. Ma L, Hu B, Liu Y, et al. Human embryonic stem cellderived GABA neurons correct locomotion deficits in quinolinic acid-lesioned mice. Cell Stem Cell 2012;10:455-64.

87. Nakanishi K, Sato Y, Mizutani Y, et al. Rat umbilical cord blood cells attenuate hypoxic-ischemic brain injury in neonatal rats. Sci Rep 2017;7:44111.

88. Meschia JF, Brott T. Ischaemic stroke. Eur J Neurol 2018;25:35-40. 